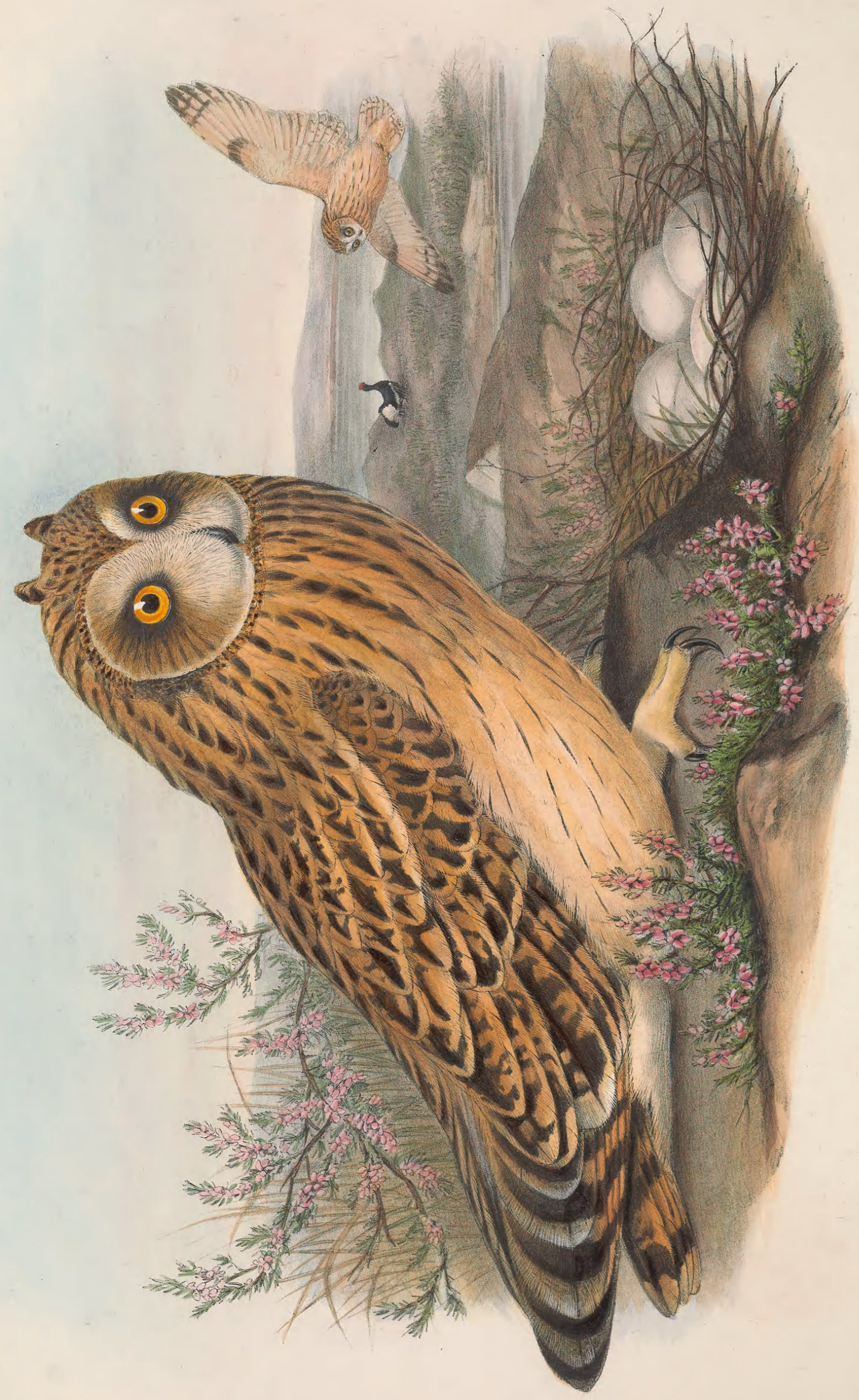




\section{BRACHYOTUS PALUSTRIS.}

\section{Short-eared Owl.}

Strix brachyotos, Gmel. edit. Linn. Syst. Nat., tom. i. p. 289.

_ agolius, Pall. Zoog. Ross. As., tom. i. p. 309.

—ulula, Gmel. edit. Linn. Syst. Nat., tom. i. p. 294.

_ accipitrina, Pall. Itin., vol. i. p. 445.

_ caspia, Shaw. Gen. Zool., vol. vii. p. 272.

— palustris, Bechst. Vög. Deutsch., tom. ii. p. 344

_brachyura, Nils. Faun. Suec., tom. i. p. 62.

_ arctica, Sparm. Mus. Carls., pl. 51.

Otus brachyotus, Steph. Cent. of Shaw's Gen. Zool., vol. xiii. pt. 2. p. 57.

Brachyotus palustris, Gould, Birds of Europe, vol. i. pl. 40.

europaus, Bonap. Consp. Gen. Av., tom. i. p. 51.-Brachyotus, sp. 1

Thene are in nearly every group of birds certain species which are eminently cosmopolitan-wanderers, as it were, over the whole (or nearly the whole) surface of our globe; and the present bird may be regarded as the cosmopolite among the Owls, since it ranges so widely that there are few countries which it does not inhabit. It is true that the ornithologists of the United States consider their bird to be distinct from the Short-eared Owl of the Old World; but the difference between them is, in my opinion, too slight to warrant their being regarded in that light.

Wherever a bird breeds, that country may justly claim it as one of its indigenous inhabitants : hence this $\mathrm{Owl}$ may be so considered in the British Islands; for although there is an immigration from the north about the end of October, and a corresponding diminution in spring, yet considerable numbers did formerly, and many now, remain to breed in England, Scotland, and Ireland. We have abundant evidence that this bird inhabits the African continent, from north to south. Mr. Jerdon states that it arrives in India at the beginning of the cold weather, and leaves again about March, spreading itself in the interval over the entire Peninsula, from Cape Comorin to the Himalayas, and being often flushed and killed by the florican-hunters. Every country of the European continent enumerates it in the list of its avifauna. It is common on the Amur, and doubtless in every part of China. In America, it frequents the furcountries in summer, and at other seasons the whole of the northern States, from east to west. When speaking of this species in my 'Birds of Europe,' I stated that I had seen examples from other portions of the New World, even as far as the southernmost parts of Chili; and although I cannot now refer to the specimens, I am inclined to believe that I was correct in so saying. In Australia, New Zealand, and Polynesia it has never been found; neither have I any reason to suppose that it is a native of any of the Indian Islands, such as Borneo, Java, the Philippines, and Japan; everywhere else this flapping diurnal Owl appears to be either a constant resident or a migrant.

In England, this bird is known to sportsmen as the Woodcock Owl, from the circumstance of its numbers being greatly augmented about the time of the arrival of that bird in November; in all probability, both species are under the same influence, and compulsorily leave the coast of Norway with the first favourable wind. In November, then, great accessions to the numbers of this bird are observed to take place on our eastern shores, whence they spread themselves over the entire country, and are frequently to be met with, in the latter part of the Partridge-season, among the great turnip-fields and low sedgy flats of Norfolk, Suffolk, and Cambridge and Huntingdon shires. Certain districts are occasionally overrun with the common Field-Mouse to such an extent that the young plantations would be entirely destroyed, were their numbers not kept down by the Short-eared $\mathrm{Owl}$. Instances are on record of from ten to twenty being seen together; and hence it has been regarded by some as a gregarious bird, which indeed it is, so long as there is an abundance of this kind of food, but no longer: the mice failing, it feeds upon any other small quadrupeds and birds it may be able to obtain. Colonel Montagu found the remains of a Skylark and a Yellowhammer in the stomach of one he examined, Mr. Thompson the legs of a Tringa, and Mr. Yarrell a half-grown rat and portions of a bat.

These terrestrial habits will inform my readers that this is not a woodland bird, like the Long-eared $\mathrm{O}_{w l}$; and this difference in the situations they frequent, together with certain variations in their structure, induces me to consider them as generically distinct.

Sir William Jardine states, "On the extensive moors at the Head of Dryfe, a small rivulet in Dumfriesshire, I have, for many years past, met with one or two pairs of these birds; and the accidental discovery of their young first turned my attention to the range of their breeding. The young was discovered 
by one of my dogs pointing it; and the following year two nests, with five eggs, were found. They were upon the ground, among the heath, the bottom of the nest scraped until the fresh earth appeared, on which the eggs were placed, without any lining or accessory covering. When approaching the nest or young, the old birds fly and hover round, uttering a shrill cry, and snapping with their bills ; they will then alight at a short distance, survey the aggressor, and again resume their flight and cries. The young are barely able to fly by the 12th of August, and appear to leave the nest some time before they are able to rise from the ground. I have taken them, on that great day to sportsmen, squatted on the heath, like young black game, at no great distance from each other, and always attended by the parent birds: last year (1831) I found them in their old haunts, to which they appear to return very regularly." That the bird breeds still further south in the British Islands is proved by the following remarks of Mr. Stevenson, of Norwich :- "While planting and cultivation have induced the Long-eared $\mathrm{O}$ wl to become a regular denizen of this country, drainage and the enclosure of commons and waste lands have banished the Short-eared Owl from its former breedinggrounds. In the south-western parts of Norfolk, where fens are now almost entirely done away with, this species bred regularly; and its nests were also taken occasionally in the vicinity of the coast. It still visits us regularly, and very numerously, in autumn." Mr. F. Bond has taken several nests in Wicken and the adjoining feus near Burwell, in Cambridgeshire; but these fens are now drained.

Mr. Wheelwright, who writes so interestingly in the "Field' under the name of "An Old Bushman," says :- "The Short-eared $\mathrm{Owl}$ is a summer migrant in Lapland, arriving towards the end of May, and during the whole season it is very common on the fells. It frequents exactly the same tracts as the Merlin, and, although perhaps more nocturnal than diurnal in its habits, is very often seen hawking over the fells in broad daylight. Its flight much resembles that of the Goatsucker. It is a very bold bird; and I once saw a Short-eared Owl actually beat off a Golden Eagle from the vicinity of its nest. I have often been amused, while lying by my camp-fire on the fells at midnight, by watching the curious evolutions of this bird in the air, which greatly reminded me of those of the Common Lapwing. Its loud cry, "Wau-wau," much resembles the barking of a dog. We took one fresh nest, May 29."

Mr. Wolley, in a paper read at the Meeting of Scandinavian Naturalists, at Christiania, in 1856, mentions that "This bird has a singular habit, when in fear for its nest, of suddenly casting itself down on the ground, in a place where it is hidden from the sight of the passer-loy, and there wailing like a woman in fright or danger." This fact, he adds, has no doubt given rise to a story which he had heard among some of the Lapps, relating to a supernatural bird, which they say sometimes makes a visit to their encampments, darting down upon a spot whence a tent has lately been removed, seizing a fragment of skin or fur from the dress of one of the family, and flying away with it. "Presently it returns and again darts down, but this time on the spot where the owner of the fragment will be buried. There it cries and moans like one in the agonies of death, and just as that person whose fate is thus indicated will, at his or her end, wail and moan."

Mr. Alfred Newton informs me that, during the first week in August 1854, his brother Edward and himself, when riding over a heath at Elveden, disturbed a Short-eared Owl, which made a great outcry, rising ligh into the air, and then dashing down with a piercing scream. "We proceeded to search, and soon came upon a half-fledged young one, sheltered in the heather, by the side of which a freshly-killed rat had been deposited. A day or two after, we found that, notwithstanding the anxiety shown by the parent bird, this young one had been abandoned by it since our visit, and was dead. We, however, discovered another of the brood close by; but this too was in like manner deserted, though we had been careful not so much as to touch it. Not wishing to cause the deaths of the remainder of the family; for there were doubtless some more hidden in the heather, we made no further search; and though the jealous temper of the old bird hardly deserved to be rewarded, I trust the rest of the brood attained to maturity. The Owlets we found had probably strayed to a considerable distance from the nest; for we looked over the ground so carefully that, had it been near at hand, it could not have escaped us."

Mr. Jerdon considers it probable that this is the Owl that is not unfrequently hawked at by falconers in the North-western provinces of India; and in confirmation of this view, Mr. Wolf informs me that he once released a Short-eared Owl from a springe, which, on flying away, was pounced upon by a Goshawk that had been secretly sitting on a neighbouring tree, and carried it off in its talons.

The buffy tint of the breast varies from yellowish red to light buff and yellowish white. In some specimens the longitudinal stripes on the centre of the breast and flank-feathers are very narrow, in others broad. When fully adult, the colours of the two sexes assimilate very closely; and the young, from their first assumption of feathers after the downy state, partake of the colouring of the adult.

The Plate represents the bird, with its nest and eggs, of the natural size. 


\section{$2 \mathrm{BHL}$ Biodiversity Heritage Library}

Gould, John. 1873. "Short-eared Owl, Brachyotus palustris [PI. 32]." The birds of Great Britain 1, -. https://doi.org/10.5962/p.323811.

View This Item Online: https://www.biodiversitylibrary.org/item/221495

DOI: https://doi.org/10.5962/p.323811

Permalink: https://www.biodiversitylibrary.org/partpdf/323811

\section{Holding Institution}

Smithsonian Libraries

\section{Sponsored by}

Biodiversity Heritage Library

\section{Copyright \& Reuse}

Copyright Status: Public domain. The BHL considers that this work is no longer under copyright protection.

This document was created from content at the Biodiversity Heritage Library, the world's largest open access digital library for biodiversity literature and archives. Visit BHL at https://www.biodiversitylibrary.org. 